\title{
sciendo
}

\section{SKIN MUCOSAL, SERUM IMMUNITY AND ANTIOXIDANT CAPACITY OF COMMON CARP (CYPRINUS CARPIO) FED ARTEMISIA (ARTEMISIA} $A N N U A)$

Iman Sarhadi ${ }^{1}$, Ebrahim Alizadeh ${ }^{1}$, Ehsan Ahmadifar ${ }^{1 *}$, Hossein Adineh ${ }^{2}$, Mahmoud A.O. Dawood ${ }^{3}$

\author{
${ }^{1}$ Department of Fisheries, Faculty of Natural Resources, University of Zabol, Zabol, Iran \\ ${ }^{2}$ Department of Fisheries Science, Faculty of Agriculture and Natural Resources, Gonbad Kavous \\ University, Iran \\ ${ }^{3}$ Department of Animal Production, Faculty of Agriculture, Kafrelsheikh University, Kafrelsheikh, \\ Egypt \\ •Corresponding author: ehsan.ahmadifar@uoz.ac.ir
}

\begin{abstract}
In this study, the effect of artemisia (Artemisia annua) leaves extract (ALE) on the immune system, growth performance and antioxidant capacity of common carp (Cyprinus carpio) was investigated. Fish with initial weight of $90.32 \pm 1.12 \mathrm{~g}$ were fed various levels of $\mathrm{ALE}(0,0.5,1$ and $1.5 \mathrm{~g} / \mathrm{kg}) \mathrm{for}$ 8 weeks. The results showed that the growth performance (FW, WG, SGR, PER, and LER) in fish fed $1 \mathrm{~g} / \mathrm{kg}$ ALE was increased significantly $(P<0.05)$ and the feed conversion ratio (FCR) was improved in fish fed 1 and $1.5 \mathrm{~g} / \mathrm{kg} \mathrm{ALE}$ in comparison to the control group $(P<0.05)$. Skin mucus total protein was higher in fish fed diet containing $0.5 \mathrm{~g} / \mathrm{kg}$ ALE than the other experimental groups $(P<0.05)$, while the lysozyme, immunoglobulin and protease were increased by increasing of ALE in diets. Respiratory burst activity and serum immune parameters were higher in fish fed $0.5 \mathrm{~g} / \mathrm{kg}$ ALE than the other treatments $(P<0.05)$. Increasing of catalase (CAT) and decreasing of malondialdehyde (MDA) were observed in fish fed ALE, while glutathione peroxidase (GPx) increased only in fish fed $0.5 \mathrm{~g} / \mathrm{kg}$ ALE. Hence, it can be concluded that ALE has considerable potential as a natural immunostimulant and growth promotor supplement for the common carp's aquaculture.
\end{abstract}

Key words: Artemisia annua extract, antioxidant activity, Cyprinus carpio, growth performance, immune parameters

Nowadays, aquaculture industry continues to grow rapidly in relation to other animal feed-producing sectors (Dawood, 2016; Shekarabi et al., 2019; Srichaiyo et al., 2020). The use of intensive and super intensive systems has been rapidly developed in aquaculture industry, which can accelerate the disease outbreaks and lead to heavy economic losses (Ahmadifar et al., 2019 a; Carbone and Faggio, 2016; Dawood et al., 2016; El Megid et al., 2020). A great amount of antibiotics and chemotherapeutics have been used in aquaculture to boost growth performance and inhibit disease 
prevalence, nevertheless, numerous undesirable repercussions have arisen such as food safety concerns, drug resistant pathogens and environmental impact (Dawood et al., 2019 e; Giri et al., 2015; Sun et al., 2018; Wang et al., 2015). Therefore, alternative strategies to antibiotics and chemotherapeutics which cause the same impact or increase protection to farm fish are extremely required through using natural immunostimulants (Abdel-Tawwab et al., 2017; Dawood et al., 2019 c; Van Hai, 2015; Watts et al., 2017). The utilization of natural herbs has been of great interest to promote animal's immune system and provide protection against infectious pathogens (Amin et al., 2019; Dawood et al., 2019 b; El-Deep et al., 2019; Saleh et al., 2019; Van Hai, 2015). Their characteristics and features enable them to promote growth and improve immune system and antimicrobial activities as well as appetizers and anti-stress traits (Abdelkhalek et al., 2017; Ahmadifar et al., 2019 b; Citarasu, 2010). Medicinal plants have little side effects, are easily degradable, and are abundantly available, making them as cheap and sustainable natural immunostimulants (Jian and Wu, 2003, 2004; Moustafa et al., 2019; Wang et al., 2019 a, b).

Artemisia annua is one of the medicinal plants belonging to the genus in Asteraceae. This plant is grown in vast regions of the world, including the Northern Hemisphere, Australia, Africa, and South and Central America (Brisibe et al., 2008, 2009). Many nutrients and phytochemical elements are available in A. annua, especially artemisinin and phenolic compounds which can contribute to a healthy diet with possible antioxidant activity (De Ridder et al., 2008).

One of the most important farmed freshwater fish species in the world is common carp (Cyprinus carpio) (FAO, 2018). Recently, positive effect of several herbal plants such as ferula (Ferula asafoetida) (Safari et al., 2016), Persian hogweed (Heracleum persicum) (Hoseinifar et al., 2016), loquat (Eriobotrya japonica) (Hoseinifar et al., 2018), olive leaf extract (Zemheri-Navruz et al., 2019), Psidium guajava (Hoseinifar et al., 2019 a), rosemary leaf powder (Yousefi et al., 2019), jujube (Ziziphus jujuba Mill.) (Hoseinifar et al., 2019 b), Ginkgo biloba leaf extract (Bao et al., 2019), and lavender (Lavandula angustifolia) (Yousefi et al., 2020) was observed in common carp. However, there is no information about the application of $A$. annua on the performances of common carp. Therefore, this study seeks to investigate the impact of $A$. annua leaves on the cutaneous mucosal, serum immune parameters, growth performance and antioxidant response of common carp.

\section{Material and methods}

\section{Artemisia leaf extract and diet preparation}

Artemisia plant was collected from Golestan Province, Iran, and it has been recognized by the Botanists of Golestan University, Iran. A. annua leaves extract (ALE) was obtained in compliance with the protocol prescribed by Sadeghi-Nejad et al. (2010). The collected leaves were dried and crushed into fine powder, then $10 \mathrm{~g}$ powder was mixed with $100 \mathrm{ml}$ ethanol (80\%). Using Whatman filter paper, the extract was filtered and concentrated by solvent evaporation in ambient condition 
for $72 \mathrm{~h}$. The obtained ALE extract was mixed entirely with the other ingredients in a mixer and pelleted via a meat grinder as reported by Safari et al. (2016). The pellets were dried and kept at the temperature of $4^{\circ} \mathrm{C}$ in plastic bags until being used. The proximate composition (crude protein, crude lipid, crude ash, and crude fibre) of the experimental diets was quantified by following AOAC (1995) (Table 1). ALE was supplemented into the basal diet at 0 (control group), $0.5,1$, and $1.5 \mathrm{~g} \mathrm{ALE} / \mathrm{kg}$ feed.

Table 1. Ingredient and composition of the experimental diets

\begin{tabular}{lcll}
\hline \multicolumn{1}{c}{ Ingredient } & $\%$ & \multicolumn{1}{c}{ Composition } & $\%$ \\
\hline Fish meal & 40 & Dry matter & 89.5 \\
Wheat flour & 21 & Crude protein & 38.22 \\
Soybean meal & 13.5 & Crude lipid & 13.24 \\
Wheat gluten & 5.5 & Ash & 3.45 \\
Soybean oil & 6 & Fiber & 11.2 \\
Fish oil & 6 & & \\
Mineral premix $^{\mathrm{a}}$ & 3 & & \\
Vitamin premix $^{\mathrm{a}}$ & 2 & & \\
Binder $^{\mathrm{b}}$ & 2 & & \\
Anti fungic $^{\mathrm{c}}$ & 0.5 & & \\
Antioxidant $^{\mathrm{d}}$ & 0.5 & & \\
\hline
\end{tabular}

${ }^{a}$ Vitamin mixture (g/100 g vitamin mix except vitamins $A$ and $\left.\mathrm{D}_{3}\right)$ : vitamin $\mathrm{A}, 180000 \mathrm{IU}$; vitamin $\mathrm{D}_{3}$, 60000 IU; vitamin E, 4; vitamin C, 6; K , 0.3; thiamine, 0.8, riboflavin, 0.6; niacin, 2; pyridoxine, 0.4; pantothenic acid, 3.5; biotin, 0.5; folic acid, 0.3; cyanocobalamin, 0.8; inositol, 2; Mineral mixture (g/100 g mineral mix): $\mathrm{Fe}, 2.5 ; \mathrm{Mg}, 3 ; \mathrm{K}, 3.5 ; \mathrm{Mn}, 1.7 ; \mathrm{Co}, 0.05 ; \mathrm{Cu}, 0.5 ; \mathrm{Se}, 0.25 ; \mathrm{I}, 0.1$.

${ }^{b}$ Amet binderTM, Mehr Taban-e-Yazd, Iran.

'ToxiBan antifungal (Vet-A-Mix, Shenan-doah, IA).

${ }^{\mathrm{d} B u t y l a t e d ~ h y d r o x y t o l u e n e ~(B H T) ~(M e r c k, ~ G e r m a n y) . ~}$

\section{Feeding trial and fish culture}

Common carp were obtained from a local hatchery in Golestan Province and taken to the laboratory of Gonbad University in Iran. Fish health status was verified by normal coloration, the absence of cysts, spots or patches over the body and gills and normal behavioral signs (swimming and feeding reflexes). Then, fish were stored in four fiberglass tanks with a volume of $400 \mathrm{~L}$ and fed a basal diet to acclimatize to laboratory condition for two weeks. Thereafter, fish $(90.32 \pm 1.12 \mathrm{~g})$ were distributed into 12 tanks $200 \mathrm{~L}$ (10 fish per replicate; $n=30$ fish/group) in a random manner. Fish were fed four times a day with $3 \%$ of body weight for 8 weeks as a feeding trial. Tanks were cleaned and syphoned every day by $30 \%$ water exchange using dechlorinated tap water. During the experiment, water quality parameters including temperature, $\mathrm{pH}$, and dissolved oxygen were checked regularly and were in the following range respectively: $27 \pm 1.15^{\circ} \mathrm{C}, 7.83 \pm 0.28$ and $5.78 \pm 0.30$. The current trial followed a standard operating procedure approved by the animal care and use committee of Gonbad University, Iran. Fish were starved for $24 \mathrm{~h}$ and then anesthetized by clove powder $(500 \mathrm{mg} / \mathrm{L})$ prior to sampling at the end of the experiment (Safari et al., 2019). It is worth mentioning that growth performance parameters and feed conversion ratio were measured as follows: 
Weight gain $(\mathrm{WG}, \mathrm{g})=\mathrm{W}_{\mathrm{F}}-\mathrm{W}_{\mathrm{I}}$; Specific growth rate $\left(\mathrm{SGR}, \%\right.$ day $\left.^{-1}\right)=100 \times$ $\left(\mathrm{LnW}_{\mathrm{F}}-\mathrm{LnWI}\right) / \mathrm{d}$; Condition factor $(\mathrm{CF})=100 \times \mathrm{W} / \mathrm{L}^{3}$; Protein efficiency ratio $(\mathrm{PER})=\left(\mathrm{W}_{\mathrm{F}}-\mathrm{W}_{\mathrm{I}}\right) / \mathrm{PF}$; Feed conversion ratio $(\mathrm{FCR})=\mathrm{F} /\left(\mathrm{W}_{\mathrm{F}}-\mathrm{W}_{\mathrm{I}}\right)$; Lipid efficiency ratio $(\mathrm{LER})=\left(\mathrm{W}_{\mathrm{F}}-\mathrm{W}_{\mathrm{I}}\right) / \mathrm{LF}$; Survival rate $=\left(\mathrm{N}_{\mathrm{F}} / \mathrm{N}_{\mathrm{I}}\right) \times 100$.

$\mathrm{W}_{\mathrm{I}}(\mathrm{g})$ is fish initial body weight, $\mathrm{W}_{\mathrm{F}}(\mathrm{g})$ is fish final body weight, $\mathrm{d}$ (day) is duration of the experiment, F is total feed supplied (g, dry basis), L is the total fish length, PF is total protein feed (g, dry basis) and LF is total lipid feed (g, dry basis), $\mathrm{N}_{\mathrm{I}}$ and $\mathrm{N}_{\mathrm{F}}$ are numbers of fish at initial and final stages of experiment, respectively.

\section{Immunological assays}

\section{Skin mucus and serum preparation}

The samples of skin mucus were gathered following the procedure presented by Subramanian et al. (2007) and Ross et al. (2000). After being anesthetized, fish were put in separate bags made up of polyethylene having $10 \mathrm{~mL}$ of $50 \mathrm{mM} \mathrm{NaCl}$ (Sigma, Steinheim, Germany) for about 1 minute to collect skin mucus (9 fish per treatment). For this purpose, the researchers softly rubbed the fish inside the plastic downwards. Then, fish were transferred and put in their correspondent tanks. Afterwards, samples of skin mucus were immediately taken to $15-\mathrm{ml}$ sterile centrifuge tubes, centrifuged (5810 R Engelsdorf, Germany) $\left(1500 \times \mathrm{g}\right.$ at $4{ }^{\circ} \mathrm{C}$ for 10 minutes) and kept in $2-\mathrm{mL}$ tubes at $-80^{\circ} \mathrm{C}$ for further analysis.

Total number of 9 fish were sampled from each group randomly collected and anesthetized in order to perform serum isolation. Then, the researchers took the blood from caudal vein by a 5 -mL syringe and 27 -gauge needle. The samples were left to clot for $4 \mathrm{~h}$ at a temperature of $4^{\circ} \mathrm{C}$. The samples were finally centrifuged, and the serum was collected and stored at a temperature of $-80^{\circ} \mathrm{C}$ until being used.

\section{Evaluation of immune parameters}

Levels of serum and mucus total immunoglobulin (Ig) were analysed based on the procedure proposed by Siwicki (1993). The method for microprotein specification (C-690; Sigma) was used to measure serum total protein content before and after precipitating the immunoglobulin molecules by $12 \%$ polyethylene glycol solution (Sigma). The modified turbidimetric method explained by Ellis et al. (2001) was employed to measure the serum and skin mucus lysozyme activity. Aliquots (1.75 $\left.\mathrm{Ml}^{-1}\right)$ of Micrococcus lysodeikticus (Sigma, USA) suspension (0.375 $\mathrm{mg} \mathrm{Ml}^{-1}$, $0.05 \mathrm{M}$ PBS, $\mathrm{pH}$ 6.2) were blended with $250 \mu \mathrm{L}^{-1}$ of each sample, and after 15 and $180 \mathrm{~s}$ the optical density was measured by a spectrophotometer (Biophotometer Eppendorf) at $670 \mathrm{~nm}$. It was decided to define one unit of lysozyme activity as reduction in absorbance of $0.001 / \mathrm{min}$. Lysozyme units in serum were calculated based on the standard curve produced by white lysozyme (Sigma, USA).

Azocasein hydrolysis method, with a slight modification, was used to measure the protease activity in skin mucus (Ross et al., 2000). $100 \mu \mathrm{l}$ of skin mucus was poured in $100 \mu \mathrm{l}$ of $0.7 \%$ azocasein solution (sigma) and subsequently incubated with constant agitation at $30^{\circ} \mathrm{C}$ for 19 hours. To stop the reaction, $4.5 \%$ trichloroacetic acid was added and the reaction mixture was centrifuged at $15000 \mathrm{~g}$ for 5 minutes to obtain the supernatant. The supernatant was collected via pipette and poured into 
a 96-well flat bottom plate which had been seeded with $100 \mu \mathrm{L} 1 \mathrm{~N}$ sodium hydroxide $(\mathrm{NaOH})$ per well. Optical density $(\mathrm{OD})$ was evaluated at $450 \mathrm{~nm}$. The protease activity was depicted with respect to a positive control (trypsin solution of $5 \mathrm{~mL}^{-1}$ substituted mucus; $100 \%$ protease activity).

Following Yano et al. (1992) rabbit red blood cells (RaRBC) were used to assay the alternative pathway activity of complement system (ACH50) in serum samples. The volume which yielded 50\% hemolysis was identified and employed for computing complement activity of sample (ACH50) as below:

ACH50 value (unit $\left.\mathrm{ml}^{-1}\right)=1 / \mathrm{k}^{*}($ reciprocal of the serum dilution $) \times 0.5$

\section{Respiratory burst activity}

To measure the oxidative burst obtained from leukocyte of blood samples, researchers in this study employed chemiluminescent assay (CL) (light emission measurement) method as utilized by Takayama et al. (1998) by means of an automated system for CL assay (LUMI skan Ascent T392, Finland). The results obtained from light emission are presented as relative light units per second (RLU s $\left.{ }^{-1}\right)$ detected by a luminometer. The CL assays were carried out twice and subsequent evaluations were performed using the mean of replicate assays.

\section{Evaluation of antioxidant enzyme parameters}

Serum superoxide dismutase (SOD) activity was evaluated by using McCord and Fridovich (1969) method. As suggested in the method, we used a solution containing $100 \mu \mathrm{l}$ of phenazine methosulfate, $300 \mu \mathrm{l}$ of nitro blue tetrazolium and $1.2 \mathrm{ml}$ sodium pyrophosphate buffer. Subsequently, $1000 \mu \mathrm{l}$ water and $200 \mu \mathrm{l}$ of the serum were added to reach a total volume of $2800 \mu \mathrm{l}$, followed by adding $200 \mu \mathrm{l}$ of NADH to initiate the reaction and incubate for 1.5 minutes at $30^{\circ} \mathrm{C}$ and activities stopped by adding $1000 \mu \mathrm{l}$ of glacial acetic acid. This solution was then combined with 4.0 $\mathrm{ml}$ of $n$-butanol and incubated at room temperature to rest for $10 \mathrm{~m}$. The mixture was centrifuged and chromogen concentration in the butanol layer was evaluated at $560 \mathrm{~nm}$ using spectrophotometer (UNICO UV-2100 PC spectrophotometer, UNICO, Beijing, China). In this method, one unit of enzyme activity was determined by the rate of the enzyme which hindered $50 \%$ of NBT enzymatic reduction per minute.

Serum catalase activity was studied using the method introduced by Aebi (1984). Serum catalase activity was conducted by evaluating the reduced spectrophotometric absorbance at $240 \mathrm{~nm}(\mathrm{e}=40 \mathrm{M} / \mathrm{cm})$ with $13.2 \mathrm{Mm} \mathrm{H}_{2} \mathrm{O}_{2}$ in $50 \mathrm{Mm}$ phosphate buffer ( $\mathrm{pH} 7.0$ ), and $100 \mu \mathrm{l}$ serum was utilized as control. Furthermore, the glutathione peroxidase activity (GPx) was measured relying on the procedure suggested by Noguchi et al. (1973). GPx degrades $\mathrm{H}_{2} \mathrm{O}_{2}$ upon occurrence of reduced glutathione (GSH). GPx activity is demonstrated as $1 \mu \mathrm{mol} \mathrm{L}^{-1}$ of the substrate (GSH) depleted in 1 minute per $\mathrm{mg}$ of protein in $1 \mathrm{~mL}$ of serum.

Thiobarbituric acid reactive substances known as malondialdehyde (MDA) concentration were measured using colorimetrical methods introduced by Buege and Aust (1978). In this method, $2 \mathrm{ml}$ of thiobarbituric acid (TBA) reagent containing $0.25 \mathrm{~N} \mathrm{HCL}, 0.375 \% \mathrm{TBA}$, and $15 \%$ trichloroacetic acid was mixed with $200 \mu \mathrm{l}$ of serum. Subsequently, samples were heated to boil for $15 \mathrm{~min}$ and later cooled down 
and centrifuged. Supernatants were collected and the absorbance was calculated by a spectrophotometer at $532 \mathrm{~nm}$. Lipid peroxidation was measured via 1,3,3,3 tetraethoxypropane as standard and defined as TBARS concentration.

\section{Statistical analysis}

After testing and confirming the normality of the data through using Kolmogorov-Smirnov test, SPSS (Ver. 17) and one-way analysis of variance (ANOVA) were employed for data analysis comparing the significant differences between groups, respectively. Tukey multiple range tests were performed when differences were significant. The mean values were recorded to be significantly different at $\mathrm{P}<0.05$.

\section{Results}

\section{Growth parameters}

The final weight, weight gain, specific growth rate, protein efficiency ratio, and lipid efficiency ratio were significantly $(\mathrm{P}<0.05)$ improved in fish fed diet containing $1 \mathrm{~g} \mathrm{ALE} / \mathrm{kg}$ diet as compared to the control group without difference with the other treatments (Table 2). However, feed conversion ratio was decreased significantly in the fish fed 1 or $1.5 \mathrm{~g} \mathrm{ALE} / \mathrm{kg}$ diet compared to that of the control treatment (Table 2; $\mathrm{P}<0.05$ ). The survival rate ranged from 92.42 to $98.35 \%$ with insignificant differences among the experimental groups $(\mathrm{P}>0.05)$. Insignificant differences were also obtained for the body length and condition factor of fish fed ALE at different levels (Table 2).

Table 2. Growth parameters of common carp fed different levels of dietary A. annua extract for 8 weeks*

\begin{tabular}{|c|c|c|c|c|}
\hline \multirow{2}{*}{ Parameters } & \multicolumn{4}{|c|}{ Artemisia annua extract $(\mathrm{g} / \mathrm{kg})$} \\
\hline & 0 & 0.5 & 1 & 1.5 \\
\hline Initial weight (g) & $90.35 \pm 0.91$ & $90.20 \pm 0.89$ & $90.46 \pm 1.08$ & $90.28 \pm 1.20$ \\
\hline Final weight (g) & $130.63 \pm 5.99 \mathrm{~b}$ & $133.64 \pm 7.88 \mathrm{ab}$ & $143.70 \pm 10.62 \mathrm{a}$ & $140.32 \pm 8.97 \mathrm{ab}$ \\
\hline $\mathrm{WG}(\mathrm{g})^{1}$ & $40.28 \pm 2.03 \mathrm{~b}$ & $43.44 \pm 2.61 \mathrm{ab}$ & $53.24 \pm 4.78 \mathrm{a}$ & $50.04 \pm 5.25 \mathrm{ab}$ \\
\hline Initial length $(\mathrm{cm})$ & $18.24 \pm 1.34$ & $18.20 \pm 1.12$ & $18.26 \pm 1.64$ & $18.23 \pm 1.11$ \\
\hline Final length $(\mathrm{cm})$ & $19.52 \pm 1.22$ & $19.66 \pm 0.96$ & $20.17 \pm 1.05$ & $19.95 \pm 1.17$ \\
\hline $\operatorname{SGR}\left(\% \mathrm{day}^{-1}\right)^{2}$ & $0.61 \pm 0.07 \mathrm{~b}$ & $0.65 \pm 0.10 \mathrm{ab}$ & $0.76 \pm 0.12 \mathrm{a}$ & $0.73 \pm 0.1 \mathrm{ab}$ \\
\hline $\mathrm{CF}(\%)^{3}$ & $1.75 \pm 0.05$ & $1.75 \pm 0.05$ & $1.74 \pm 0.06$ & $1.77 \pm 0.17$ \\
\hline $\mathrm{FCR}^{4}$ & $2.52 \pm 0.17 \mathrm{a}$ & $2.38 \pm 0.32 \mathrm{ab}$ & $1.94 \pm 0.21 \mathrm{~b}$ & $2.05 \pm 0.16 \mathrm{~b}$ \\
\hline $\mathrm{PER}^{5}$ & $1.08 \pm 0.07 \mathrm{~b}$ & $1.17 \pm 0.09 \mathrm{ab}$ & $1.43 \pm 0.12 \mathrm{a}$ & $1.35 \pm 0.11 \mathrm{ab}$ \\
\hline $\mathrm{LER}^{6}$ & $5.03 \pm 0.34 \mathrm{~b}$ & $5.43 \pm 0.48 \mathrm{ab}$ & $6.65 \pm 0.42 \mathrm{a}$ & $6.25 \pm 0.30 \mathrm{ab}$ \\
\hline Survival (\%) & $92.42 \pm 3.71$ & $98.00 \pm 5.98$ & $95.18 \pm 5.45$ & $98.35 \pm 3.59$ \\
\hline
\end{tabular}

*Values are mean \pm standard deviation of three determinations. Small letters $\left({ }^{\mathrm{a}, \mathrm{b}}\right)$ in the same line indicate significant differences $(P<0.05)$ of treatment.

${ }^{1} \mathrm{WG}$ (g), weight gain (g); ${ }^{2} \mathrm{SGR}$, specific growth rate (SGR, \% day $\left.{ }^{-1}\right) ;{ }^{3} \mathrm{CF}$, condition factor $(\%) ;{ }^{4} \mathrm{FCR}$, feed conversion ratio; ${ }^{5} \mathrm{PER}$, protein efficiency ratio; ${ }^{6} \mathrm{LER}$, lipid efficiency ratio. 


\section{Serum immune parameters}

Respiratory burst activity and immunoglobulin levels (Ig) of fish fed ALE at $0.5 \mathrm{~g} / \mathrm{kg}$ were significantly $(\mathrm{P}<0.05)$ higher than the control group with insignificant $(\mathrm{P}>0.05)$ differences with those fed 1 or $1.5 \mathrm{~g}$ ALE/ $\mathrm{kg}$ diet (Figure 1 and Figure $2 \mathrm{C}$ ). Lysozyme activity was significantly higher in fish fed ALE at $0.5 \mathrm{~g} / \mathrm{kg}(\mathrm{P}<0.05)$ than the control and $1.5 \mathrm{~g} / \mathrm{kg}$ groups with insignificant $(\mathrm{P}>0.05)$ differences with those fed $1 \mathrm{~g} \mathrm{ALE} / \mathrm{kg}$ diet (Figure $2 \mathrm{~A})$. ACH50 was significantly $(\mathrm{P}<0.05)$ increased in fish fed 0.5 or $1 \mathrm{~g} / \mathrm{kg}$ groups with insignificant $(\mathrm{P}>0.05)$ differences with those fed $1.5 \mathrm{~g} \mathrm{ALE} / \mathrm{kg}$ diet (Figure $2 \mathrm{D})$. However, insignificant $(\mathrm{P}>0.05)$ differences were observed in the total serum protein of fish fed varying level of ALE (Figure $2 \mathrm{~B}$ ).

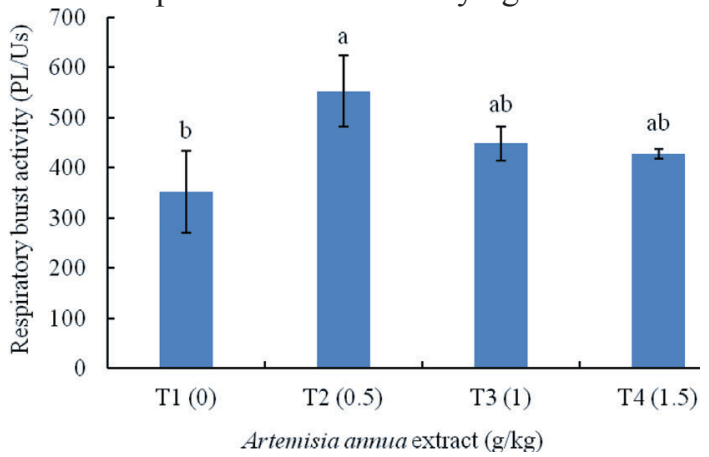

Figure 1. Respiratory burst activity of common carp fed with different levels of $A$. annua extract for 8 weeks. Values are mean $\pm \operatorname{SD}(n=3)$. Small letters $(\mathrm{a}, \mathrm{b})$ on the bars indicate significant differences $(\mathrm{P}<0.05)$ of treatment

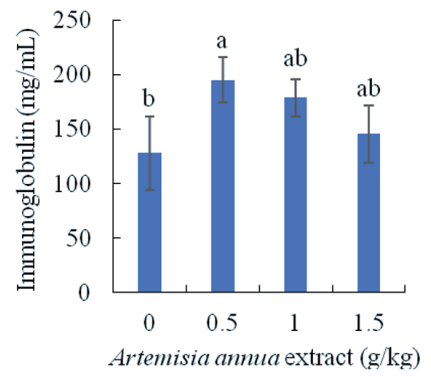

(C)
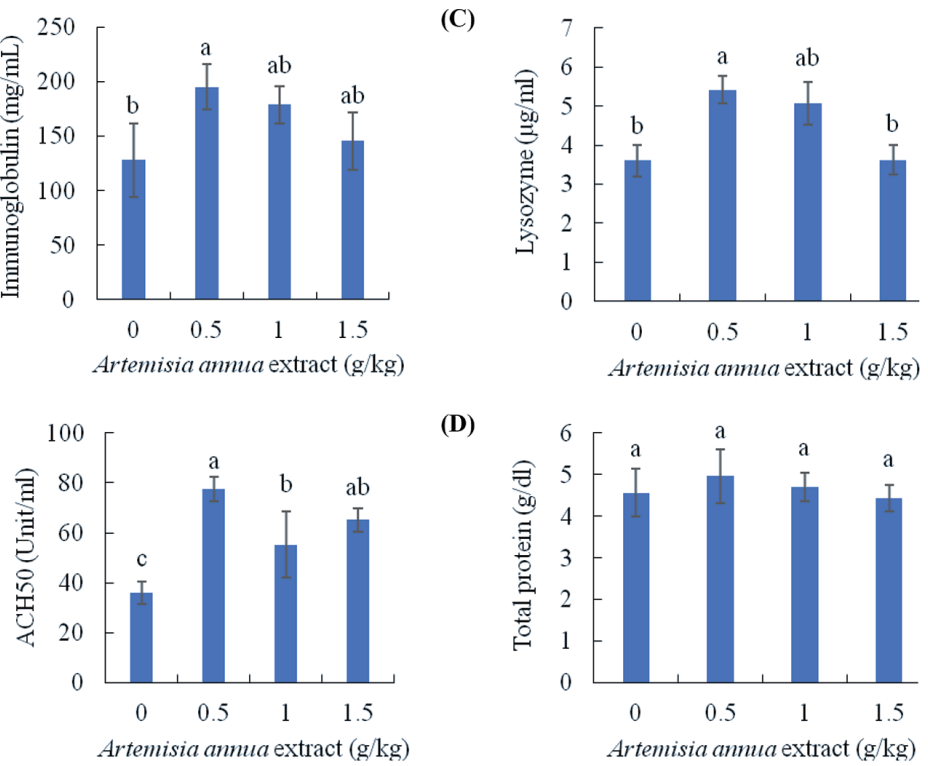

(D)

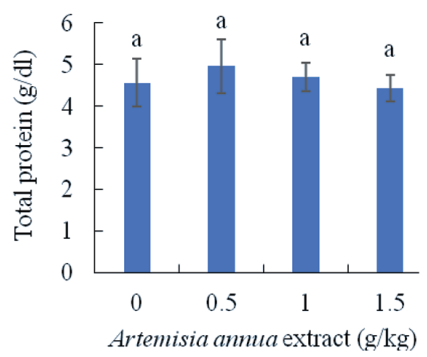

(A)

(B)

Figure 2. Serum immune parameters (A) lysozyme activity, (B) serum total protein, (C) immunoglobulin, and (D) the alternative pathway activity of complement system (ACH50) of common carp fed with different levels of $A$. апnиa extract for 8 weeks. Values are mean $\pm \operatorname{SD}(n=3)$. Small letters $(\mathrm{a}, \mathrm{b})$ on the bars indicate significant differences $(\mathrm{P}<0.05)$ of treatment 


\section{Mucus immune parameters}

Mucus total protein of fish fed ALE at $0.5 \mathrm{~g} / \mathrm{kg}$ was significantly $(\mathrm{P}<0.05)$ higher than the control group with insignificant $(\mathrm{P}>0.05)$ differences with those fed 1 or $1.5 \mathrm{~g} \mathrm{ALE} / \mathrm{kg}$ diet (Figure $3 \mathrm{~A}$ ). Lysozyme activity was improved only in fish fed $1.5 \mathrm{~g} \mathrm{ALE} / \mathrm{kg}$ diet as compared to the other groups $(\mathrm{P}<0.05$; Figure $3 \mathrm{~B})$. Mucus Ig levels of fish fed ALE were significantly $(\mathrm{P}<0.05)$ improved as compared to the control group with the highest being in 1 and $1.5 \mathrm{~g} / \mathrm{kg}$ groups (Figure $3 \mathrm{C}$ ). Mucus protease was also improved in fish fed ALE at $1.5 \mathrm{~g} / \mathrm{kg}$ without significant differences with those fed 0.5 or $1 \mathrm{~g} \mathrm{ALE} / \mathrm{kg}$ diet (Figure $3 \mathrm{D}$ ).

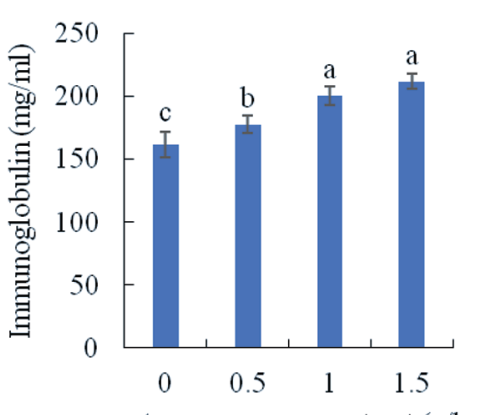

(C)

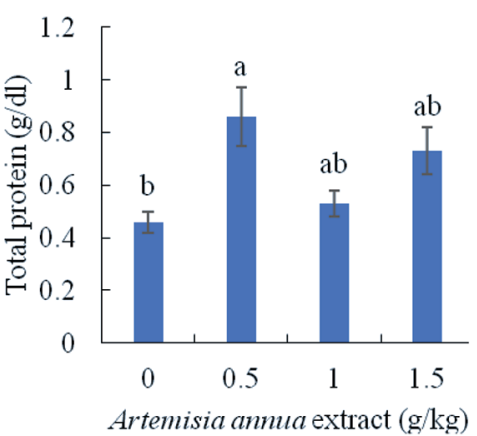

(A)

Artemisia anmua extract $(\mathrm{g} / \mathrm{kg}$

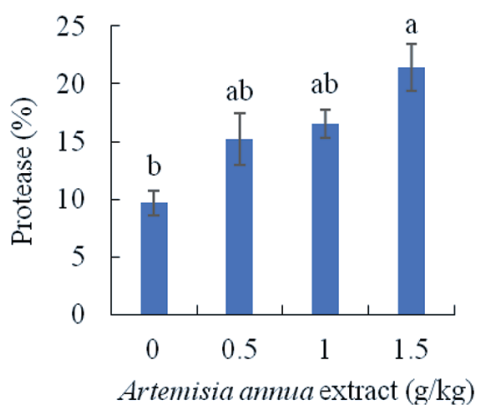

(D)

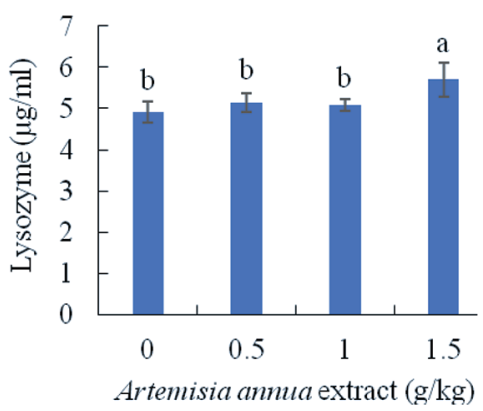

(B)

Figure 3. Mucus immune parameters (A) total protein, (B) lysozyme activity, (C) immunoglobulin, and (D) protease level of common carp fed with different levels of $A$. annua extract for 8 weeks. Values are mean $\pm \mathrm{SD}(n=3)$. Small letters $(\mathrm{a}, \mathrm{b})$ on the bars indicate significant differences $(\mathrm{P}<0.05)$ of treatment

\section{Antioxidant activity}

Serum antioxidant activity in common carp fed varied levels of ALE is given in Figure 4. Catalase activity of fish fed with 0.5 and $1 \mathrm{~g} \mathrm{ALE} / \mathrm{kg}$ diet was significantly $(\mathrm{P}<0.05)$ higher than the other treatments (Figure $4 \mathrm{~A})$. GPx showed higher activity in fish fed with the diet containing $0.5 \mathrm{~g} \mathrm{ALE} / \mathrm{kg}$ diet than the other treatments (Figure $4 \mathrm{C}$ ). SOD activity was insignificantly affected by ALE supplementation (Figure $4 \mathrm{~B}$ ), while the MDA level was decreased significantly in fish fed ALE at 0.5, 1, and $1.5 \mathrm{~g} / \mathrm{kg}$ as compared to the control group with the lowest being in fish fed $0.5 \mathrm{~g}$ $\mathrm{ALE} / \mathrm{kg} \operatorname{diet}(\mathrm{P}<0.05$; Figure $4 \mathrm{D})$. 


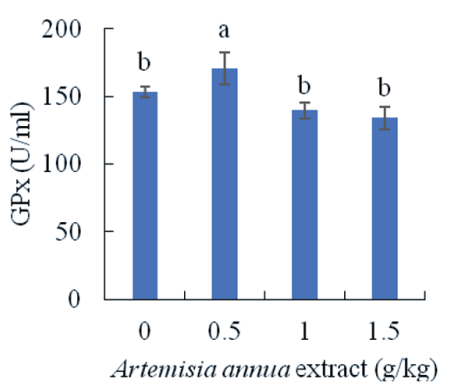

(C)

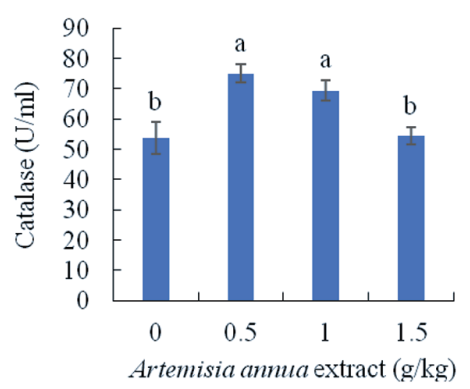

(A)

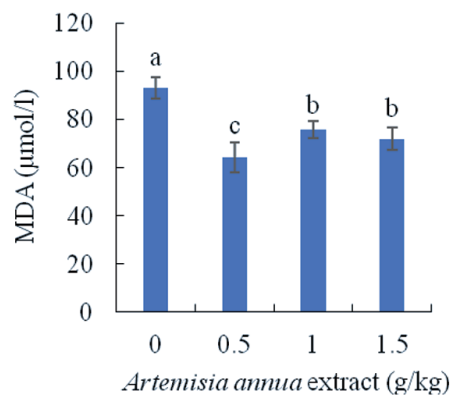

(D)

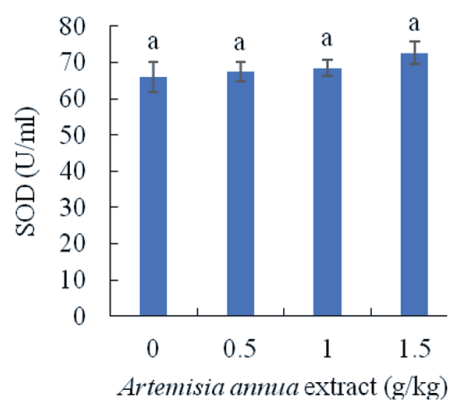

(B)

Figure 4. Serum antioxidant activity (A) catalase, (B) serum superoxide dismutase activity (SOD), (C) glutathione peroxidase activity (GPx), and (D) malondialdehyde concentration (MDA) of common carp fed with different levels of $A$. annua extract for 8 weeks. Values are mean $\pm \operatorname{SD}(n=3)$. Small letters $(a, b)$ on the bars indicate significant differences $(\mathrm{P}<0.05)$ of treatment

\section{Discussion}

Extensive investigations on diverse ranges of medical plants (whole plant, parts of plant or extract) and algal extracts revealed potentially beneficial effects of these herbal additives on performance, immune response, and oxidative resistance of several fish species (Adel et al., 2019; Dawood et al., 2018, 2019 c; Hoseini et al., 2019; Saeidi asl et al., 2017; Safari et al., 2019; Van Doan et al., 2019 a, b). In this sense, the present study was performed to investigate antioxidant defense, immune response, growth and feed efficiency of common carp following supplementation of ALE in diet.

ALE resulted in improved growth performance in common carp in the current study. Growth performance and feed conversion ratio are essential parameters needed to judge the potential use of feed additives in aquafeed (Moss et al., 2019; Yan et al., 2017; Zaineldin et al., 2018). The present study determined that ALE significantly improved the final body weight, WG, SGR, protein efficiency ratio and lipid efficiency ratio of common carp, while concurrently reducing FCR. It has been demonstrated that the medicinal plants can act as growth promoters by boosting the digestive enzymes which in turn can increase the growth rates and survival of aquatic animals (Faggio et al., 2015; Van Hai, 2015). ALE is also rich with many 
essential elements including crude protein, essential amino acids, minerals, vitamins, antioxidants, and flavonoids which are vital for the growth and feed utilization in animals (Brisibe et al., 2008; Tanaya et al., 2013). Likewise, Allen et al. (1997) indicated that $A$. annua improved the feed efficiency and weight gain of broilers. In line with our results, supplementation of palm fruit extracts (Hoseinifar et al., 2017 a), rosemary leaf powder (Yousefi et al., 2019), lavender extract (Yousefi et al., 2020), polyphenols (Jahazi et al., 2019), jujube fruit extract (Hoseinifar et al., 2019 b), had beneficial effects on common carp growth performance and feed utilization. Safari et al. (2016) reported that the improved growth performance and feed intake can be attributed to the up-regulation of growth and appetite related genes expression $(G H$, $I G F 1$ and $G h r l$ ) in common carp fed on ferula powder.

ALE has been found to possess immunomodulatory and antioxidative properties, which have been attributed to the monomer polyphenolic compounds which may help in improving the health status and the growth performance of animals (Ahmad et al., 2010; Chen et al., 2014; Koul et al., 2018; Naghavi et al., 2014). The findings of the present study also showed the potential of ALE to be used as a dietary phyto immunostimulant for common carp. Fish that received diets supplemented with ALE elicited considerable modulated immune responses including remarkable serum and skin mucus immune responses.

Blood immunoglobulins, complement, and lysozyme as the key elements in the genesis of the immune response (Magnadóttir, 2006), are among the most frequently tested immune parameters in herbal supplemented diets in fish (Van Doan et al., 2017; Watts et al., 2017). The present results indicated improved blood Ig, ACH50, and lysozyme activity which are similar with the results obtained from previous trials suggesting the beneficial roles of herbs and their extracts/active components to stimulate the immune system in common carp. The highest Ig, ACH50, and lysozyme activity were observed in fish fed 0.5 to $1 \mathrm{~g} \mathrm{ALE} / \mathrm{kg}$ diet which is almost similar to the growth performance parameters. Yousefi et al. (2019) and Yousefi et al. (2020) reported that the rosemary leaf powder or lavender extract improved the blood Ig, ACH50, and lysozyme activity in common carp. Dietary supplement with polyphenols showed enhancement of blood lysozyme and Ig in common carp (Jahazi et al., 2019). Hoseinifar et al. (2018) showed that dietary loquat leaf extract significantly increased the blood Ig, ACH50, and lysozyme activity in common carp. Therefore, elevation of total Ig, ACH50 and lysozyme hint at possible immunomodulatory effects of ALE in common carp.

Fish defense system, in which the integument provides the first line of defense, is rather complicated. As Ángeles Esteban (2012) points out skin mucus and its components have a significant effect as hindering various sorts of pathogens and exo-parasites. Meanwhile, skin mucus is reportedly affected by environmental conditions, nutrition and feed additives (Dawood et al., 2017 a, b; Lazado and Caipang, 2014). The results of this study showed a rise in non-specific immune parameters (total Ig, lysozyme and protease activity) in the skin mucus of common carp. In fact, fish fed $1.5 \mathrm{~g} \mathrm{ALE} / \mathrm{kg}$ diet demonstrated the highest level of the measured parameters. Lysozyme, as one constituent of the innate immunity system, contributes to non-specific immunity of animal by their anti-inflammatory and bactericidal properties (Ángeles 
Esteban, 2012). Moreover, the higher lysozyme activity correlated with more antibacterial activity versus gram-positive and gram-negative bacteria. The obtained results exhibited a significant increase in levels of skin mucus lysozyme in fish fed $1.5 \mathrm{~g} \mathrm{ALE} / \mathrm{kg}$ diet. As protective function, skin mucus proteases have a pivotal role in hindering the pathogenic invasion both by hindering their invasion mechanisms and colonization and cleaving their proteins (Subramanian et al., 2007). Diets containing ALE could significantly increase skin mucus proteases activity and the highest values were recorded at inclusion level of $1.5 \mathrm{~g} / \mathrm{kg}$ ALE. A similar improved skin mucus immunity was observed in common carp fed ferula (Safari et al., 2016), medlar extracts (Hoseinifar et al., 2017 b), polyphenols (Jahazi et al., 2019), jujube fruit extract (Hoseinifar et al., 2019 b), and P. guajava (Hoseinifar et al., 2019 a). However, no study was found on the effect of ALE on non-specific immune response of fish. In broilers, Khalaji et al. (2011) reported that artemisia leaves mixed with black cumin seeds have improved the immune response. Immunosuppressive activity of artemisinin (as component in artemisia) was investigated on mice and revealed the activity of artemisinin as an immunosuppressive agent (Noori et al., 2004). Also, Zhang and Sun (2009) reported that the cellular and humoral response in mice can increase by ethanolic extract of $A$. аппиа. The immunomodulatory effects can be ascribed to the availability of carvacrol, artemisinin and polysaccharides in A. anпua.

The results obtained in the current study implied that respiratory burst activity in treated fish was notably higher than in the control group. Akbay et al. (2003) has demonstrated the capability of flavonoid glycosides of nettle in modulating the oxidative burst and degranulation of properly stimulated human neutrophils. Apparently, the same could take place in respiratory burst activity of common carp. Results also revealed that antioxidant enzymes activities (SOD, CAT and GPx) were increased in fish fed with ALE. The antioxidant defense system comprises the enzymes including superoxide dismutase (SOD), catalase (CAT) and glutathione peroxidase (GPx), and is proposed to provide the lowest levels of reactive oxygen species in animal cells (Holmblad and Söderhäll, 1999; Otto and Moon, 1996; Pandey et al., 2003). Considering our findings, similar improved SOD, CAT, and GPx activities were observed in common carp fed rosemary leaf powder (Yousefi et al., 2019), lavender extract (Yousefi et al., 2020), ferula (Safari et al., 2016), polyphenols (Jahazi et al., 2019), and palm fruit extracts (Hoseinifar et al., 2017 a). Although Dhibi et al. (2016) stated that plants are a potential source for providing natural antioxidant, the effect of dietary ALE on antioxidant enzyme in common carp has not been investigated yet. A. апnиa is a rich source of sesquiterpene lactones and antioxidant compounds (flavonoids, phenolic acids, cineol, a-pinene, and camphor, etc.) with potential benefits to animal health (Brisibe et al., 2009; Cai et al., 2004; Hoseini et al., 2019; Jahazi et al., 2019; Mirghaed et al., 2019). Flavonoids of this plant also have a high amount of essential oil such as; cineol, a-pinene, camphene, camphor and artemisia keton which can increase the antioxidative response (Kim et al., 2009; Radulović et al., 2013). Thus, this study explored the effect of different ALE levels on antioxidant enzyme activities in common carp.

The over levels of reactive oxygen species (ROS) can increase the lipid peroxidation which resulted in malonaldehyde (MDA) production. The continuous existing 
of MDA can damage the organism cell by breaking down the DNA, protein and cytoplasm (Dawood et al., 2019 a, d; Yao et al., 2010). Our results revealed lower MDA consideration and higher SOD, CAT and GPx activities in fish fed with ALE indicated reduced cell damage compare to fish fed the control diet. Medicinal herbs have functional compounds that enhanced the secretion of antioxidant enzymes and helped in scavenging superoxide radicals (Ferreira et al., 2010). These compounds have high reducing and antioxidant properties due to the presence of hydroxyl group and unsaturated bonds in their chemical structure. Accordingly, phenolic acid and gallic acid are the potent phenolic antioxidants, which can increase the antioxidant properties of the extracts by creating hybrids with other phenolic compounds such as caffeic acid (Awad and Awaad, 2017). Moreover, the existence of quercetin, a flavonoid antioxidant in artemisia due to the lack of glycogen in its structure has high antioxidant capacity (Awad and Awaad, 2017). Similar to the present study, Yousefi et al. (2020) reported declined MDA in common carp fed dietary lavender extract. The increase of antioxidant enzyme activity in the present study was consistent with the increase of immune parameters.

\section{Conclusion}

In conclusion, it can be observed that artemisia ( $A$. annua) leaves extract had affected beneficially most of the tested factors in common carp. The results confirmed the potential of ALE as a growth promotor and stimulatory agent. Dietary ALE supplementation at 0.5 to $1 \mathrm{~g} / \mathrm{kg}$ is recommended for common carp to suppress oxidative conditions and augment the immune responses. Further studies are needed to evaluate the effects of ALE under infectious bacterial challenge using transcriptomic tools for supporting our knowledge regarding the mode of action and optimum inclusion level.

\section{Acknowledgments}

The authors are thankful to the staff of fisheries Laboratory at University of Zabol (Grant code: UOZ-GR-9618-104) and Gonbad University for their cordial assistance during the experiment.

\section{References}

A b d e l- Taw w a b M., A b b a s s F.E. (2017). Turmeric powder, Curcuma longa L., in common carp, Cyprinus carpio L., diets: growth performance, innate immunity, and challenge against pathogenic Aeromonas hydrophila infection. J. World Aquacult. Soc., 48: 303-312.

A b d e 1 k h a 1 e k N.K.M.,E i s s a I.A.M.,A h m e d E.,K i 1 a n y O.E.,E 1 - A d 1 M.,D a w o o d M.A.O., Has s a n A.M., Abde l-Daim M.M. (2017). Protective role of dietary Spirulina platensis against diazinon-induced oxidative damage in Nile tilapia, Oreochromis niloticus. Environ. Toxicol. Pharmacol., 54: 99-104.

A de 1 M., D aw o od M.A.O., Sh a fi e i S., S a kha i e F., Sh e k a rabi S.P.H. (2019). Dietary Polygonum minus extract ameliorated the growth performance, humoral immune parameters, immunerelated gene expression and resistance against Yersinia ruckeri in rainbow trout (Oncorhynchus mykiss). Aquaculture, 519: 734738.

A e b i H. (1984). Catalase in vitro, Methods in enzymology. Elsevier, pp. 121-126. 
A h m a d W., Has a n A., A b d u 11 a h A., Ta r a n n u m T. (2010). Medicinal importance of Artemisia absinthium Linn (Afsanteen) in Unani medicine: A review. Hipp. J. Unani Med., 5: 117-125.

A h madifar E., S a d e gh T.H., Daw o od M.A.O., D a d a r M., Sheikhzad eh N. (2019 a). The effects of dietary Pediococcus pentosaceus on growth performance, hemato-immunological parameters and digestive enzyme activities of common carp (Cyprinus carpio). Aquaculture, 516: 734656.

A hmadifar E., Daw ood M.A.O., Moghadam M.S., Sheikhzadeh N., Hoseini fa r S.H., M u s th a f M.S. (2019 b). Modulation of immune parameters and antioxidant defense in zebrafish (Danio rerio) using dietary apple cider vinegar. Aquaculture, 734412.

A k b a y P., B a s a ran A.A., Undeger U., B a s a r a n N. (2003). In vitro immunomodulatory activity of flavonoid glycosides from Urtica dioica L. Phytotherapy Research: An. Inter. J. Devot. Pharmacol. Toxicol. Evalu. Natur. Prod. Deriv., 17: 34-37.

A 11 e n P.C., L y d o n J., D a n for th H.D. (1997). Effects of components of Artemisia annua on coccidia infections in chickens. Poultry Sci., 76: 1156-1163.

Amin A., El Asely A., Abd El-Naby A.S., Samir F., E1-Ashram A., Sudhakar a n R., D a w o o d M.A.O. (2019). Growth performance, intestinal histomorphology and growthrelated gene expression in response to dietary Ziziphus mauritiana in Nile tilapia (Oreochromis niloticus). Aquaculture, 512: 734301.

Ánge les Es te b a n M. (2012). An overview of the immunological defenses in fish skin. ISRN Immunology, 2012.

AOAC (1995). Official methods of analysis of AOAC International, 16th ed. AOAC International, Arlington, 1.

Aw a d E., Aw a a d A. (2017). Role of medicinal plants on growth performance and immune status in fish. Fish Shellfish Immunol., 67: 40-54.

B a o L., Chen Y., Li H., Zhang J., Wu P., Ye K., A i H., Chu W.J.F. (2019). Dietary Ginkgo biloba leaf extract alters immune-related gene expression and disease resistance to Aeromonas hydrophila in common carp Cyprinus carpio. Fish Shellfish Immunol., 94: 810-818.

B ris ibe E.A., Umoren U.E., Ow a i P.U., B ris ibe F. (2008). Dietary inclusion of dried $A r-$ temisia annua leaves for management of coccidiosis and growth enhancement in chickens. Afr. J. Biotechnol., 7: 4083-4092.

B ris ibe E.A., Umoren U.E., B ris ibe F., Magalhäes P.M., F erreira J.F., Luthria D., W u X., Pri o r R.L. (2009). Nutritional characterisation and antioxidant capacity of different tissues of Artemisia annua L. Food Chem., 115: 1240-1246.

B u e g e J.A., A u s t S.D. (1978). Microsomal lipid peroxidation, Methods in enzymology. Elsevier, pp. 302-310.

C a i Y., Lu o Q., S un M., C orke H. (2004). Antioxidant activity and phenolic compounds of 112 traditional Chinese medicinal plants associated with anticancer. Life Sci J., 74: 2157-2184.

Carbone D., Faggio C. (2016). Importance of prebiotics in aquaculture as immunostimulants. Effects on immune system of Sparus aurata and Dicentrarchus labrax. Fish Shellfish Immunol., 54: $172-178$.

Ch en J., Wang X., Li u C. (2014). Anti-tumour effects of polysaccharides isolated from Artemisia annua $\mathrm{L}$. by inducing cell apoptosis and immunomodulatory anti-hepatoma effects of polysaccharides. Afr. J. Tradit. Complement. Altern. Med., 11: 15-22.

C i t a r a s u T. (2010). Herbal biomedicines: a new opportunity for aquaculture industry. Aquacult. Int., 18: 403-414.

D aw o o d M.A.O. (2016). Effect of various feed additives on the performance of aquatic animals. Kagoshima University.

D aw o o d M.A.O., K o s hi o S., I s h i k aw a M., Yok o y a m a S. (2016). Effects of dietary inactivated Pediococcus pentosaceus on growth performance, feed utilization and blood characteristics of red sea bream, Pagrus major juvenile. Aquacult. Nutr, 22: 923-932.

D aw o od M.A., Koshio S., I shikaw a M., El-S abagh M., Yok oy ama S., Wang W.L., Yukun Z., Olivier A. (2017 a). Physiological response, blood chemistry profile and mucus secretion of red sea bream (Pagrus major) fed diets supplemented with Lactobacillus rhamnosus under low salinity stress. Fish Physiol. Biochem., 43: 179-192.

Daw ood M.A.O., Koshio S., El-Sabagh M., Billah M.M., Zaineldin A.I., Za- 
ye d M.M., O mar A.A.E.-D. (2017 b). Changes in the growth, humoral and mucosal immune responses following $\beta$-glucan and vitamin $\mathrm{C}$ administration in red sea bream, Pagrus major. Aquaculture, 470: 214-222.

D a w o od M.A.O., K o shi o S., E s te b a n M.Á. (2018). Beneficial roles of feed additives as immunostimulants in aquaculture: a review. Rev Aquacult., 10: 950-974.

D a w o od M.A., Shu kry M., Z a y e d M.M., O mar A.A., Z a in e $1 \mathrm{~d}$ in A.I., E 1 B a s u in i M.F. (2019 a). Digestive enzymes, immunity and oxidative status of Nile tilapia (Oreochromis niloticus) reared in intensive conditions. Slov. Vet. Res., 56 (Suppl 22): 99-108.

D a w o o d M.A.O., K o s h i o S. (2019 b). Application of fermentation strategy in aquafeed for sustainable aquaculture. Rev. Aquacult., 1-16.

D a w o od M.A.O., Koshi o S., A bde l- D a i m M.M., Van D o an H. (2019 c). Probiotic application for sustainable aquaculture. Rev. Aquacult., 11: 907-924.

D a w o o d M.A.O., E w e e d a h N.M., M o u s t a f a E.M., F a r a h a t E.M. (2019 d). Probiotic effects of Aspergillus oryzae on the oxidative status, heat shock protein, and immune related gene expression of Nile tilapia (Oreochromis niloticus) under hypoxia challenge. Aquaculture, 734669.

D a w o o d M.A.O., M g g o u z F.I., S a 1 e m M.F.I., E 1 b i a l y Z.I., A b d e l- D a i m H.A. (2019 e). Synergetic effects of Lactobacillus plantarum and beta-glucan on digestive enzyme activity, intestinal morphology, growth, fatty acid, and glucose-related gene expression of genetically improved farmed tilapia. Probiotics Antimicro., 1-11.

De Ridder S., Van der Kooy F., Verpoorte R. (2008). Artemisia annua as a self-reliant treatment for malaria in developing countries. J. Ethnopharmacol., 120: 302-314.

Dhibi S., B o u ze n na H., S a m out N., T lili Z., El fek i A., H fa i e dh N. (2016). Nephroprotective and antioxidant properties of Artemisia arborescens hydroalcoholic extract against oestroprogestative-induced kidney damages in rats. Biomed Pharmacother., 82: 520-527.

E 1 - D e e p M.H., D a w o od M.A.O., A s s a r M.H., I j ir i D., O h ts u k a A. (2019). Dietary Moringa oleifera improves growth performance, oxidative status, and immune related gene expression in broilers under normal and high temperature conditions. J. Therm. Biol., 82: 157-163.

E1 Megid A.A.,Abd Al Fatah M.E., El Asely A., El Senosi Y., Moustafa M.M.A., D a w o o d M.A.O. (2020). Impact of pyrethroids and organochlorine pesticides residue on $I G F-1$ and CYP1A genes expression and muscle protein patterns of cultured Mugil capito. Ecotox. Environ. Safe., 188: 109876.

E 11 is A.J.D., I m m u n o 1 og y C. (2001). Innate host defense mechanisms of fish against viruses and bacteria. Dev. Comp. Immunol., 25: 827-839.

Fagg i o C., Fazio F., Marafiot i S., A rfus o F., Pic cione G. (2015). Oral administration of Gum Arabic: effects on haematological parameters and oxidative stress markers in Mugil cephalus. Iran. J. Fish. Sci., 14: 60-72.

FAO (2018). Aquaculture Department, The state of world fisheries and aquaculture, Food and Agriculture Organization of the United Nations, Rome, 2430.

Ferre ir a J.F., L u thri a D.L., S a s a k i T., He y e ri ck A. (2010). Flavonoids from Artemisia an$n и a \mathrm{~L}$. as antioxidants and their potential synergism with artemisinin against malaria and cancer. Molecules, 15: 3135-3170.

Giri S.S., S en S.S., Chi C., K i m H.J., Yun S., P ark S.C., S u ku maran V. (2015). Effect of guava leaves on the growth performance and cytokine gene expression of Labeo rohita and its susceptibility to Aeromonas hydrophila infection. Fish Shellfish Immunol., 46: 217-224.

Holmblad T., Söderhäll K. (1999). Cell adhesion molecules and antioxidative enzymes in a crustacean, possible role in immunity. Aquaculture, 172: 111-123.

Ho s e in i S.M., You s e fi M., Ho s e in i far S.H., Van Do a n H.J.A. (2019). Antioxidant, enzymatic and hematological responses of common carp (Cyprinus carpio) fed with myrcene- or menthol-supplemented diets and exposed to ambient ammonia. Aquaculture, 506: 246-255.

H o s e in i far S.H., Z o h e ir i F., L a z a d o C.C.J.F. (2016). Dietary phytoimmunostimulant Persian hogweed (Heracleum persicum) has more remarkable impacts on skin mucus than on serum in common carp (Cyprinus carpio). Fish Shellfish Immunol., 59: 77-82.

Hose in if ar S.H., Dadar M., Khalili M., C erezuela R., Esteban M.Á. (2017 a). Effect of dietary supplementation of palm fruit extracts on the transcriptomes of growth, antioxidant enzyme and immune-related genes in common carp (Cyprinus carpio) fingerlings. Aquacult Res., 48: 3684-3692. 
Ho s e in if ar S.H., Z o u H.K., M i and a r e H.K., Van D o a n H., R o mano N., D a dar M.J.F. (2017 b). Enrichment of common carp (Cyprinus carpio) diet with medlar (Mespilus germanica) leaf extract: Effects on skin mucosal immunity and growth performance. Fish Shellfish Immunol., 67: 346-352.

Hoseinifar S.H., Zou H.K., Van Doan H., Kolangi Miandare H., Hoseini S.M. (2018). Evaluation of some intestinal cytokines genes expression and serum innate immune parameters in common carp (Cyprinus carpio) fed dietary loquat (Eriobotrya japonica) leaf extract. Aquacult. Res., 49: 120-127.

Hos e in ifar S.H., S o hrabi A., P a knejad H., J a fari V., P a ol u c c i M., Van Do an H.J.F. (2019 a). Enrichment of common carp (Cyprinus carpio) fingerlings diet with Psidium guajava: the effects on cutaneous mucosal and serum immune parameters and immune related genes expression. Fish Shellfish Immunol., 86: 688-694.

Hos e in ifar S.H., Z ou H.K., Van Doan H., Harikrishnan R., Yousefi M., Paknej a d H., A h m a difar E. (2019 b). Can dietary jujube (Ziziphus jujuba Mill.) fruit extract alter cutaneous mucosal immunity, immune related genes expression in skin and growth performance of common carp (Cyprinus carpio)? Fish Shellfish Immunol., 94: 705-710.

Jahazi A., Hose in ifar S.H., Jafari V., Hajimoradloo A., Van Doan H., Paoluc c i M.J.A. (2019). Dietary supplementation of polyphenols positively affects the innate immune response, oxidative status, and growth performance of common carp, Cyprinus carpio L. Aquaculture, 517: 734709 .

J i a n J., W u Z. (2003). Effects of traditional Chinese medicine on nonspecific immunity and disease resistance of large yellow croaker, Pseudosciaena crocea (Richardson). Aquaculture, 218: 1-9.

J i a n J., W u Z. (2004). Influences of traditional Chinese medicine on non-specific immunity of Jian carp (Cyprinus carpio var. Jian). Fish Shellfish Immunol., 16: 185-191.

Khalaji S., Zaghari M., Hatami K., Hedari-Dastjerdi S., Lotfi L., Nazarian H. (2011). Black cumin seeds, Artemisia leaves (Artemisia sieberi), and Camellia L. plant extract as phytogenic products in broiler diets and their effects on performance, blood constituents, immunity, and cecal microbial population. Poultry Sci., 90: 2500-2510.

K i m E.-K., L e e S.-J., M o on S.-H., J e on B.-T., A h n C.-B., K i m B., L i m B.-O., P a rk P.-J. (2009). Free radical scavenging activity and comparative proteomic analysis of antioxidative protein against $\mathrm{H}_{2} \mathrm{O}_{2}$-induced oxidative stress in neuronal cells. Food Chem., 117: 232-240.

K o u l B., Ta ak P., Kumar A., Khatri T., S a n y a l I. (2018). The artemisia genus: a review on traditional uses, phytochemical constituents, pharmacological properties and germplasm conservation. J. Glycom. Lipidom., 7: 1-7.

L a z a d o C.C., C a i pang C.M.A. (2014). Mucosal immunity and probiotics in fish. Fish Shellfish Immunol., 39: 78-89.

Magnadóttir B.J.F. (2006). Innate immunity of fish (overview). Fish Shellfish Immunol., 20: 137-151.

M c C or d J.M., F r i d o v i c h I. (1969). Superoxide dismutase an enzymic function for erythrocuprein (hemocuprein). J. Biol. Chem., 244: 6049-6055.

Mirgh a ed A.T., F a y a z S., H o s e in i S.M.J.A. (2019). Effects of dietary 1, 8-cineole supplementation on serum stress and antioxidant markers of common carp (Cyprinus carpio) acutely exposed to ambient ammonia. Aquaculture, 509: 8-15.

Mos s A.S., Ishikaw a M., Koshio S., Yokoyama S., Dawood M.A.O. (2019). Effects of different levels of marine snail shells in the diets of juvenile Kuruma shrimps Marsupenaeus japonicus as a source of calcium. N. Am. J. Aquacult., 81: 55-66.

Moust a fa E.M., D aw ood M.A.O., A s s a r D.H., O mar A.A., E 1 bi a ly Z.I., F a rrag F.A., Shukry M., Z ayed M.M. (2019). Modulatory effects of fenugreek seeds powder on the histopathology, oxidative status, and immune related gene expression in Nile tilapia (Oreochromis niloticus) infected with Aeromonas hydrophila. Aquaculture, 734589.

Naghavi M.R., A la eimoghadam F., Ghafoori H. (2014). Artemisia species from Iran as valuable resources for medicinal uses. World Academy of Science, Engineering and Technology, Inter. Biol. Biomol. Agricult. Food Biotechnol. Engin., 8: 1194-1200.

N o g u c hi T., Can t or A.H., S c ot t M.L. (1973). Mode of action of selenium and vitamin E in prevention of exudative diathesis in chicks. J. Nutr., 103: 1502-1511. 
Noori S., Na deri G.A., H a s s a Z.M., Habibi Z., B a tha i e S.Z., H a s he mi S.M. (2004). Immunosuppressive activity of a molecule isolated from Artemisia annua on DTH responses compared with cyclosporin A. Int. Immunopharmacol., 4: 1301-1306.

O t t o D.M., M o o n T.W. (1996). Endogenous antioxidant systems of two teleost fish, the rainbow trout and the black bullhead, and the effect of age. Fish Physiol. Biochem., 15: 349-358.

Pandey S., Parvez S., S a yeed I., Haque R., B in-Hafeez B., Raisuddin S. (2003). Biomarkers of oxidative stress: a comparative study of river Yamuna fish Wallago attu (B1. \& Schn.). Sci. Total Environ., 309: 105-115.

R a du lović N.S., R and j elović P.J., S toj a nović N.M., B la goj ević P.D., S toj a novi ć - Ra dić Z.Z., Ili ć I.R., D jord jević V.B. (2013). Toxic essential oils. Part II: Chemical, toxicological, pharmacological and microbiological profiles of Artemisia annua L. volatiles. Food Chem. Toxicol., 58: 37-49.

Ros s N.W., Firth K.J., Wang A., Burka J.F., Johnson S.C. (2000). Changes in hydrolytic enzyme activities of naive Atlantic salmon Salmo salar skin mucus due to infection with the salmon louse Lepeophtheirus salmonis and cortisol implantation. Dis. Aquat. Organ., 41: 43-51.

Sadeghi-Nejad B., Shiravi F., Ghanbari S., A linejadi M., Zarrin M. (2010). Antifungal activity of Satureja khuzestanica (Jamzad) leaves extracts. Jundishapur J. Microbiol., 3: 36.

S a e id i a s 1 M.R., A d el M., C a i pang C.M.A., D a w o o d M.A.O. (2017). Immunological responses and disease resistance of rainbow trout (Oncorhynchus mykiss) juveniles following dietary administration of stinging nettle (Urtica dioica). Fish Shellfish Immunol., 71: 230-238.

S a far i O., S a r kh e i 1 M., P a o 1 u c c i M.J.F. (2019). Dietary administration of ferula (Ferula asafoetida) powder as a feed additive in diet of koi carp, Cyprinus carpio koi: effects on hemato-immunological parameters, mucosal antibacterial activity, digestive enzymes, and growth performance. Fish Physiol. Biochem., 45: 1277-1288.

S a fari R., Hos ein if ar S.H., Nejadmoghad a m S., J a far A. (2016). Transciptomic study of mucosal immune, antioxidant and growth related genes and non-specific immune response of common carp (Cyprinus carpio) fed dietary ferula (Ferula assafoetida). Fish Shellfish Immunol., 55: $242-248$.

S a l e h A.A., K ir re 11 a A.A., D a w o o d M.A.O., E b e id T.A. (2019). Effect of dietary inclusion of cumin seed oil on the performance, egg quality, immune response and ovarian development in laying hens under high ambient temperature. J. Anim. Physiol. Anim. Nutr., 103: 1810-1817.

She karabi S.P.H., Omidi A.H., Dawood M.A., Adel M., Avazeh A., Heidari F.J.A. (2019). Effect of black mulberry (Morus nigra) powder on growth performance, biochemical parameters, blood carotenoid concentration, and fillet color of rainbow trout. Ann. Anim. Sci., 19: $1-26$.

S iw i cki A. (1993). Nonspecific defense mechanisms assay in fish. II. Potential killing activity of neutrophils and macrophages, lysozyme activity in serum and organs and total immunoglobulin (Ig) level in serum. Fish diseases diagnosis and preventions methods. Wydawnictwo Instytutu Rybactwa Śródlądowego, Olsztyn, Poland, pp. 105-111.

Srichaiyo N., Tongs iri S., Ho s e in if ar S.H., Daw ood M.A.O., Jat uras itha S., Es t e ba n M.Á., Ringø E., Van D o a n H. (2020). The effects of gotu kola (Centella asiatica) powder on growth performance, skin mucus, and serum immunity of Nile tilapia (Oreochromis niloticus) fingerlings. Aquacult. Rep., 16: 100239.

Subramanian S., Ma c Kin non S.L., Ros s N.W. (2007). A comparative study on innate immune parameters in the epidermal mucus of various fish species. Comp. Biochem. Physiol. B Biochem. Mol. Biol., 148: 256-263.

S u n Z., Tan X., Ye H., Z o u C., Ye C., Wang A. (2018). Effects of dietary Panax notoginseng extract on growth performance, fish composition, immune responses, intestinal histology and immune related genes expression of hybrid grouper (Epinephelus lanceolatus $\widehat{\jmath} \times$ Epinephelus fuscoguttatus ) fed high lipid diets. Fish Shellfish Immunol, 73: 234-244.

Ta k a y a m a F., E g a s h i r a T., Y a m a n a k a Y. (1998). Assay for oxidative stress injury by detection of luminol-enhanced chemiluminescence in a freshly obtained blood sample: a study to follow the time course of oxidative injury. Nihon Yakurigaku Zasshi., 111: 177-186.

Tan a y G., Pras e n j it M., M itra P. (2013). Effect of leaves of Artemisia vulgaris L. on growth of rats. Int. J. Herb. Med., 1: 30-34. 
Van Doan H., Hose inifar S.H., Dawood M.A.O., Chitmanat C., Tayyamath K. (2017). Effects of Cordyceps militaris spent mushroom substrate and Lactobacillus plantarum on mucosal, serum immunology and growth performance of Nile tilapia (Oreochromis niloticus). Fish Shellfish Immunol., 70: 87-94.

Van Doan H., Hoseinifar S.H., Chitmanat C., Jaturasitha S., Paolucci M., A s houri G., Daw o od M.A.O., Es te ba n M.Á. (2019 a). The effects of Thai ginseng, Boesenbergia rotunda powder on mucosal and serum immunity, disease resistance, and growth performance of Nile tilapia (Oreochromis niloticus) fingerlings. Aquaculture, 734388.

Van Doan H., Hoseinifar S.H., Sringarm K., Jaturasitha S., Yuangsoi B., Daw o o d M.A.O., E s t e b a n M.Á., R in gø E., F a g g i o C. (2019 b). Effects of Assam tea extract on growth, skin mucus, serum immunity and disease resistance of Nile tilapia (Oreochromis niloticus) against Streptococcus agalactiae. Fish Shellfish Immunol., 93: 428-435.

Van Hai N. (2015). The use of medicinal plants as immunostimulants in aquaculture: a review. Aquaculture, 446: 88-96.

Wang J.-L., Meng X.-L., Lu R.-H., Wu C., Luo Y.-T., Yan X., Li X.-J., Kong X.-H., Ni e G.-X. (2015). Effects of Rehmannia glutinosa on growth performance, immunological parameters and disease resistance to Aeromonas hydrophila in common carp (Cyprinus carpio L.). Aquaculture, 435: 293-300.

Wang W., Ishikawa M., Koshio S., Yokoyama S., Dawood M.A.O., Hos s in M.S., $\mathrm{Z}$ a in e 1 d in A.I. (2019 a). Interactive effects of dietary astaxanthin and cholesterol on the growth, pigmentation, fatty acid analysis, immune response and stress resistance of kuruma shrimp (Marsupenaeus japonicus). Aquacult. Nut., 25: 946-958.

Wang W., I shikawa M., Koshio S., Yokoyama S., Dawood M.A.O., Hos s a in M.S., Mos s A.S. (2019 b). Effects of dietary astaxanthin and vitamin $E$ and their interactions on the growth performance, pigmentation, digestive enzyme activity of kuruma shrimp (Marsupenaeus japonicus). Aquacult. Res., 50: 1186-1197.

Wat t s J., S c hrei er H., L a n s k a L., Ha le M. (2017). The rising tide of antimicrobial resistance in aquaculture: sources, sinks and solutions. Mar. Drugs., 15: 158.

Y a n J., G u o C., D a w o o d M.A.O., G a o J. (2017). Effects of dietary chitosan on growth, lipid metabolism, immune response and antioxidant-related gene expression in Misgurnus anguillicaudatus. Beneficial Microbes., 8: 439-449.

Yano T., Stolen J., Fletcher T., Anderson D., Hattari S., Rowley A. (1992). Techniques in Fish Immunology. SOS Publications, Fair Haven, NJ, USA.

Yao J., Wang J.-Y., Liu L., Li Y.-X., Xun A.-Y., Zeng W.-S., Jia C.-H., We i X.-X., F e n g J.-L., Z h a o L., W an g L.-S. (2010). Anti-oxidant effects of resveratrol on mice with DSSinduced ulcerative colitis. Arch. Med. Res., 41: 288-294.

Yous efi M., Hos ein i S.M., Vatnikov Y.A., Kulikov E.V., Drukovsky S.G.J.A. (2019). Rosemary leaf powder improved growth performance, immune and antioxidant parameters, and crowding stress responses in common carp (Cyprinus carpio) fingerlings. Aquaculture, 505: 473-480.

Yous efi M., Shabunin S.V., Vatnik ov Y.A., Kulikov E.V., A d in e h H., Hamidi M.K., Ho s e in i S.M.J.A. (2020). Effects of lavender (Lavandula angustifolia) extract inclusion in diet on growth performance, innate immunity, immune-related gene expression, and stress response of common carp, Cyprinus carpio. Aquaculture, 515: 734588.

Z a in eld in A.I., Hegazi S., Koshio S., I sh i kaw a M., B a kr A., E 1 - K e re d y A.M.S., Da w o od M.A.O., D o s s o u S., Wang W., Yukun Z. (2018). Bacillus subtilis as probiotic candidate for red sea bream: Growth performance, oxidative status, and immune response traits. Fish Shellfish Immunol., 79: 303-312.

Z e m h er i - N a vru z F., A c ar Ü., Y 11 m a z S.J.F. (2019). Dietary supplementation of olive leaf extract increases haematological, serum biochemical parameters and immune related genes expression level in common carp (Cyprinus carpio) juveniles. Fish Shellfish Immunol., 89: 672-676.

Z ha n g Y., S u n H. (2009). Immunosuppressive effect of ethanol extract of Artemisia annua on specific antibody and cellular responses of mice against ovalbumin. Immunopharmacol. Immunotoxicol., 31: 625-630. 